\title{
$4 \AA ̊$ molecular sieves catalyzed ring-opening of epoxides to 1,2-diacetates with acetic anhydride
}

\author{
Masumeh Gilanizadeh* and Behzad Zeynizadeh
}

Department of Chemistry, Faculty of Science, Urmia University, Urmia 5756151818, Iran

\begin{tabular}{l}
\hline C H R O N I C L E \\
\hline Article history: \\
Received February21, 2015 \\
Received in revised form \\
April 29, 2015 \\
Accepted 2 June 2015 \\
Available online \\
2 June2015 \\
\hline Keywords: \\
Acetic anhydride \\
1,2-Diacetate \\
Epoxide \\
Molecular sieves \\
Ring-opening \\
\hline
\end{tabular}

A B S T R A C T

This study was aimed at highly stereoselective ring-opening of epoxides with acetic anhydride in the presence of molecular sieves $4 \AA$ as an efficient reagent. Yields of the 1,2-diacetates are uniformly good to excellent and the reagent may be recycled without the requirement for purification. High yields, short reaction times, ease of preparation and simple work-up procedure (filtration) are advantages of this method.

\section{Introduction}

The ring strain and polarization of carbon-oxygen bonds make epoxides versatile synthetic intermediates in organic synthesis. ${ }^{1}$ Nucleophilic ring-opening of epoxides with water to give the corresponding 1,2-diols is one of the most common reactions and the subsequent acetylation of these diols provides an effective means for the protection of hydroxyl groups and preparation of 1,2diacetoxy ester products. ${ }^{2}$ Therefore, direct transformation of epoxides to the 1,2-diacetates is a very attractive reaction. A review of the literature shows that this transformation has been achieved with the reaction of epoxides and acetic anhydride in the presence of catalysts or reagents such as $\mathrm{HCl}, \mathrm{ZnCl}_{2},{ }^{3}$ $\left(\mathrm{NH}_{4}\right)_{3}\left(\mathrm{PMo}_{12} \mathrm{O}_{40}\right)_{6},{ }^{4}$ (TBA) ${ }_{4} \mathrm{PFeW}_{11} \mathrm{O}_{39} \cdot 3 \mathrm{H}_{2} \mathrm{O},{ }^{5} \mathrm{Cp}_{2} \mathrm{TiCl}_{2},{ }^{6}$ (n-Bu $)_{4} \mathrm{NOAc}^{7}{ }^{7} \mathrm{DBU}-\mathrm{LiCl}_{2}{ }^{8} \mathrm{BF}_{3} \cdot \mathrm{Et}_{2} \mathrm{O},{ }^{9}$ cerium(III) chloride, ${ }^{10} \mathrm{NaBH}_{4},{ }^{11} \mathrm{HY}$ zeolite, ${ }^{12} \mathrm{Bu}_{3} \mathrm{P},{ }^{13} \mathrm{LiClO}_{4}{ }^{14}$ and $\mathrm{Er}(\mathrm{OTf}){ }_{3} .{ }^{15}$ Among these, only four reports detailed general values (i.e. refs. 11-13 and 15), and the others were limited in scope. Some of the previously-reported studies required expensive, exotic or hazardous reagents, extended reaction times, and/or limitation to a narrow range of epoxides. For these reasons, the development of convenient methods which use cheap and readily-available reagents is necessary.

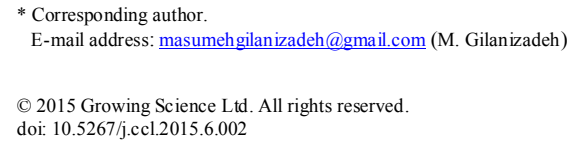


In conjunction with ongoing work in our laboratory on the catalysis of epoxide ring-opening, we observed that molecular sieves $(4 \AA)$ can be utilized as an efficient reagent to the ring-opening of epoxides with acetic anhydride under reflux to form the 1,2-diacetates in excellent yields (Scheme 1). The high yields, short reaction times, practical facility, simple filtration and catalyst recovery are advantages of this method.

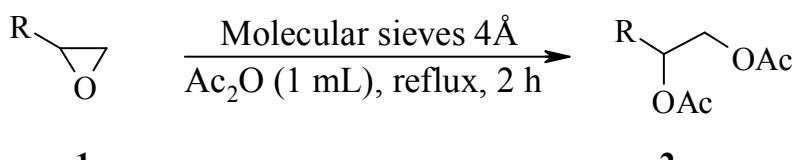

2

Scheme 1. Conversion of epoxides to 1,2-diacetates with molecular sieves $4 \AA / \mathrm{Ac}_{2} \mathrm{O}$ system

\section{Results and Discussion}

The cleavage of epoxides with acetic anhydride is unique and highly useful in organic synthesis due to production of the 1,2-diacetates as an effective protecting group. A molecular sieve is a material with very small pores in its structure, increasing contact area and activating the ring-opening of epoxides in order to proceed to the diacetate products. They appear to function as a Lewis acid upon the epoxide oxygen lone pairs to polarize the ring for heterolysis. We utilized $4 \AA$ molecular sieves in this study; these are composed of alkali metal silicic acid salts and can absorb water and other molecules with a critical diameter less than $4 \AA$. The reagent can be easily recovered and reused several times. To the best of our knowledge, the above reagent has not been employed in the ring-opening of epoxides up to now.

As illustrated in Table 1, all reactions proceeded in high to excellent yields within 2 hours or less. The results obtained from the ring-opening of different classes of epoxides containing electronreleasing or -withdrawing groups with molecular sieves in acetic anhydride as both reagent and solvent under reflux shows that the reactions were completed by using a ratio of $0.15-0.55 \mathrm{~g}$ of molecular sieves per $1 \mathrm{mmol}$ of substrate. The desired 1,2-diacetate products were obtained in $82-98 \%$ yields.

Table 1. Conversion of epoxides to 1,2-diacetates with molecular sieves $4 \AA$ in acetic anhydride

Entry Exide (a)


6<smiles>Cc1cccc(OCC2CO2)c1</smiles>

7<smiles>Cc1ccc(OCC2CO2)cc1</smiles>

8<smiles>c1ccc2cc(OCC3CO3)ccc2c1</smiles>

9<smiles>CC(C)OCC1CO1</smiles>

10<smiles>C1CCC2OC2C1</smiles>

11<smiles>CCCCC1CO1</smiles>

12<smiles>ClCC1CO1</smiles>

13<smiles>CC(=O)OCC(COc1cccc(C)c1)OC(C)=O</smiles>

0.50<smiles>CC(=O)OCC(COc1ccc(C)cc1)OC(C)=O</smiles><smiles>CC(=O)OCC(COc1ccc2ccccc2c1)OC(C)=O</smiles><smiles>CC(=O)OCC(CCl)OC(C)=O</smiles>

${ }^{\mathrm{a}} \mathrm{All}$ reactions were carried out with $1 \mathrm{mmol}$ of epoxide in refluxing $\mathrm{Ac}_{2} \mathrm{O}(1.0 \mathrm{~mL})$ within 2 hours. ${ }^{\mathrm{b}}$ Yields refer to isolated pure products.

Product analysis revealed that only one diastereomer with anti 1,2-diacetoxy groups was prepared by the reaction of cyclohexene oxide with acetic anhydride, which gives exclusively the corresponding trans-1,2-diacetate. Stereochemical assignment was achieved by: i) comparison of the obtained ${ }^{1} \mathrm{H}$ NMR spectrum with one of authentic sample reported in the literature, ${ }^{16}$ and ii) hydrolysis of rac-trans1,2-diacetoxycyclohexane to white crystalline rac-trans-1,2-cyclohexanediol (mp 101-103 ${ }^{\circ} \mathrm{C}$, found: 101-104 ${ }^{\circ} \mathrm{C}$, lit. ${ }^{17}$ ) (Scheme 2).<smiles>CC(=O)OC1CCCC[C@H]1OC(C)=O</smiles>

rac-trans-1,2-diacetate

$$
\underset{40 \text { min, reflux, } 90 \%}{\stackrel{\mathrm{K}_{2} \mathrm{CO}_{3}, \mathrm{MeOH}-\mathrm{H}_{2} \mathrm{O}}{\longrightarrow}}
$$

rac-trans-1,2-diol<smiles>OC1CCCC[C@H]1O</smiles>

Scheme 2. Hydrolysis of trans-1,2-diacetoxycyclohexane to trans-1,2-cyclohexanediol

\section{Conclusions}

In this study, $4 \AA$ molecular sieves have been used as an efficient reagent in order to form the 1,2diacetates via the ring-opening of epoxides with acetic anhydride under reflux. The amount of molecular sieves is dependent on the structure of epoxides. Some epoxides can convert to products with small amount of reagent and some of them need higher amount of reagent for fully conversion. All 
reactions were carried out by using $1 \mathrm{mmol}$ of epoxide with different amount of molecular sieves $4 \AA$. In addition, the high yields, ease of preparation, easy catalyst recovery and short reaction times are the advantages of our method.

\section{Experimental Section}

\subsection{Materials and methods}

All reagents and substrates were purchased in high-purity grade from Merck and Fluka, and were used without further purification. FT-IR and ${ }^{1} \mathrm{H} /{ }^{13} \mathrm{C}$ NMR spectra were recorded on Thermo Nicolet Nexus 670 and Bruker Avance $300 \mathrm{MHz}$ spectrometers, respectively. The products were characterized by their FT-IR and ${ }^{1} \mathrm{H} /{ }^{13} \mathrm{C}$ NMR spectra and compared with data reported in literature. All yields refer to isolated pure products. Column chromatography was carried out on short columns of silica gel 60 (230-400 mesh) in glass columns (1-2 cm diameter) using of silica gel (10-20 g per $1 \mathrm{~g}$ of isolated crude products). TLC was applied for the purity determination of the substrates, products and for monitoring of the reactions over silica gel $60 \mathrm{~F}_{254}$ aluminum sheet.

\subsection{A general procedure for conversion of epoxides to 1,2-diacetates with $4 A$ molecular sieves in acetic anhydride}

In a round-bottomed flask $(15 \mathrm{~mL})$ equipped with a condenser and a magnetic stirrer bar, molecular sieves $4 \AA(150-550 \mathrm{mg})$ were added to a solution of epoxide $(1 \mathrm{mmol})$ in acetic anhydride $(1 \mathrm{~mL})$. The reaction mixture was stirred under reflux for $2 \mathrm{~h}$. After completion of the reaction, an aqueous solution of $\mathrm{NaHCO}_{3}(5 \%, 5 \mathrm{~mL})$ was added and the mixture was stirred for additional $5 \mathrm{~min}$. The mixture was extracted with $\mathrm{CH}_{2} \mathrm{Cl}_{2}(2 \times 5 \mathrm{~mL})$ and then dried over anhydrous sodium sulfate. The eluted product was concentrated under reduced pressure and then subjected to chromatography on a normal-length silica gel column to give the pure product in excellent yield (82-98\%, Table 1).

\subsection{Physical and spectral data}

1,2-Diacetoxy-1-phenylethane (Table 1, entry 1b). Viscous liquid, FT-IR (Neat, $v \mathrm{~cm}^{-1}$ ): 3033, 2954, 1744, 1604, 1455, 1372, 1241, 1046, 1012, 950; ${ }^{1} \mathrm{H}$ NMR (300 MHz, $\left.\mathrm{CDCl}_{3}\right): \delta=2.02(\mathrm{~s}, 3 \mathrm{H}), 2.05$ $(\mathrm{s}, 3 \mathrm{H}), 4.25-4.45(\mathrm{~m}, 2 \mathrm{H}), 5.96-6.15(\mathrm{dd}, J=4.2,7.8 \mathrm{~Hz}, 1 \mathrm{H}), 7.23-7.46(\mathrm{~m}, 5 \mathrm{H}) ;{ }^{13} \mathrm{C}$ NMR $(75 \mathrm{MHz}$, $\left.\mathrm{CDCl}_{3}\right): \delta=20.83,21.05,66.08,73.32,126.93,128.39,129.01,136.22,170.00,170.58$.

1,2-Diacetoxy-3-allyloxypropane (Table 1, entry $\mathbf{2 b}$ ). Viscous liquid, FT-IR (Neat, $\left.v \mathrm{~cm}^{-1}\right)$ : 3082, $2868,1744,1647,1434,1372,1225,1093,1048,1018,957,932 ;{ }^{1} \mathrm{H}$ NMR $\left(300 \mathrm{MHz}, \mathrm{CDCl}_{3}\right): \delta=$ $2.04(\mathrm{~s}, 3 \mathrm{H}), 2.06(\mathrm{~s}, 3 \mathrm{H}), 3.55(\mathrm{~d}, J=5.1 \mathrm{~Hz}, 2 \mathrm{H}), 3.96-3.99(\mathrm{~m}, 2 \mathrm{H}), 4.14(\mathrm{dd}, J=6.3,12 \mathrm{~Hz}, 1 \mathrm{H})$, $4.32(\mathrm{dd}, J=3.9,12 \mathrm{~Hz}, 1 \mathrm{H}), 5.13-5.28(\mathrm{~m}, 3 \mathrm{H}), 5.80-5.89(\mathrm{~m}, 1 \mathrm{H}) ;{ }^{13} \mathrm{C} \mathrm{NMR}\left(75 \mathrm{MHz}, \mathrm{CDCl}_{3}\right): \delta=$ $20.67,20.79,62.81,68.07,70.22,72.26,117.34,134.14,170.26,170.58$.

1,2-Diacetoxy-3-phenoxypropane (Table 1, entry 4b). Viscous liquid, FT-IR (Neat, $v \mathrm{~cm}^{-1}$ ): 3042 , $2957,1746,1600,1588,1497,1458,1372,1228,1175,1100,1051,1019,967,887,813,756,693 ;{ }^{1} \mathrm{H}$ NMR $\left(300 \mathrm{MHz}, \mathrm{CDCl}_{3}\right): \delta=2.06(\mathrm{~s}, 3 \mathrm{H}), 2.09(\mathrm{~s}, 3 \mathrm{H}), 4.11(\mathrm{~d}, J=5.1 \mathrm{~Hz}, 2 \mathrm{H}), 4.29(\mathrm{dd}, J=6,12$ $\mathrm{Hz}, 1 \mathrm{H}), 4.43(\mathrm{dd}, J=3.9,12 \mathrm{~Hz}, 1 \mathrm{H}), 5.35-5.38(\mathrm{~m}, 1 \mathrm{H}), 6.89-6.99(\mathrm{~m}, 3 \mathrm{H}), 7.24-7.30(\mathrm{~m}, 2 \mathrm{H}) ;{ }^{13} \mathrm{C}$ NMR (75 MHz, $\left.\mathrm{CDCl}_{3}\right): \delta=20.70,20.92,62.55,65.96,69.76,114.59,121.36,129.53,158.27,170.26$, 170.57 .

1,2-Diacetoxy-3-isopropoxypropane (Table 1, entry 9b). Viscous liquid, FT-IR (Neat, $v \mathrm{~cm}^{-1}$ ): 2974 , $2875,1746,1440,1372,1225,1154,1129,1049,1017,958,921,823 ;{ }^{1} \mathrm{H}$ NMR $\left(300 \mathrm{MHz}, \mathrm{CDCl}_{3}\right): \delta$ $=1.10(\mathrm{~d}, J=6 \mathrm{~Hz}, 6 \mathrm{H}), 2.04(\mathrm{~s}, 3 \mathrm{H}), 2.06(\mathrm{~s}, 3 \mathrm{H}), 3.56-3.38(\mathrm{~m}, 3 \mathrm{H}), 4.10(\mathrm{dd}, J=3,12 \mathrm{~Hz}, 1 \mathrm{H}), 4.26$ $(\mathrm{dd}, J=3.6,12 \mathrm{~Hz}, 1 \mathrm{H}), 5.08-5.13(\mathrm{~m}, 1 \mathrm{H}) ;{ }^{13} \mathrm{C} \mathrm{NMR}\left(75 \mathrm{MHz}, \mathrm{CDCl}_{3}\right): \delta=20.64,20.73,21.84$, $21.91,62.99,66.11,76.64,77.48,170.33,170.66$.

1,2-Diacetoxycyclohexane (Table 1, entry 10b). Viscous liquid, FT-IR (Neat, $\left.v \mathrm{~cm}^{-1}\right)$ : 2944, 2866, 1736, 1453, 1368, 1231, 1043, 948, 909; ${ }^{1} \mathrm{H}$ NMR (300 MHz, $\left.\mathrm{CDCl}_{3}\right): \delta=1.28-1.35$ (m, 4H), $1.66-$ 
$1.68(\mathrm{~m}, 2 \mathrm{H}), 1.93$ (s, 3H), 1.94 (s, 3H), 1.93-1.97 (m, 2H), 4.73-4.75 (m, 2H); ${ }^{13} \mathrm{C}$ NMR (75 MHz, $\left.\mathrm{CDCl}_{3}\right): \delta=21.06,21.13,23.20,23.34,29.56,30.04,73.61,170.25,170.37$.

1,2-Diacetoxyhexane (Table 1, entry 11b). Viscous liquid, FT-IR (Neat, $v \mathrm{~cm}^{-1}$ ): 2960, 2873, 1746, $1459,1372,1225,1120,1049,961,896,843 ;{ }^{1} \mathrm{H} \mathrm{NMR}\left(300 \mathrm{MHz}, \mathrm{CDCl}_{3}\right): \delta=0.85(\mathrm{t}, 3 \mathrm{H}), 1.48-1.51$

$(\mathrm{m}, 2 \mathrm{H}), 1.53-1.55(\mathrm{~m}, 2 \mathrm{H}), 2.04(\mathrm{~s}, 3 \mathrm{H}), 2.06(\mathrm{~s}, 3 \mathrm{H}), 3.35-3.42(\mathrm{~m}, 2 \mathrm{H}), 4.10-4.33(\mathrm{~m}, 2 \mathrm{H}), 5.12-5.16$ $(\mathrm{m}, 1 \mathrm{H}) ;{ }^{13} \mathrm{C} \mathrm{NMR}\left(75 \mathrm{MHz}, \mathrm{CDCl}_{3}\right): \delta=13.81,19.15,20.72,20.99,31.53,62.92,68.79,70.27$, $170.32,170.64$.

1,2-Diacetoxy-3-chloropropane (Table 1, entry 12b). Viscous liquid, FT-IR (Neat, $\left.v \mathrm{~cm}^{-1}\right)$ : 2962 , 1744, 1437, 1372, 1224, 1048, 1016, 955, 892; ${ }^{1} \mathrm{H}$ NMR $\left(300 \mathrm{MHz}, \mathrm{CDCl}_{3}\right): \delta=2.02(\mathrm{~s}, 3 \mathrm{H}), 2.04(\mathrm{~s}$, $3 \mathrm{H}), 3.68-4.14(\mathrm{~m}, 2 \mathrm{H}), 4.18-4.32(\mathrm{~m}, 2 \mathrm{H}), 5.12-5.17(\mathrm{~m}, 1 \mathrm{H}) ;{ }^{13} \mathrm{C} \mathrm{NMR}\left(75 \mathrm{MHz}, \mathrm{CDCl}_{3}\right): \delta=20.74$, $20.81,42.09,62.18,70.37,170.04,170.35$.

\section{Acknowledgments}

The authors gratefully acknowledge the financial support of this work by the research council of Urmia University.

\section{References}

1. Aggarwal V. K., Harvey J. N., and Richardson J. (2002) Unraveling the mechanism of epoxide formation from sulfur ylides and aldehydes. J. Am. Chem. Soc., 124, 5747-5756.

2. Greene T. W., and Wuts P. G. M. (2006) Protective Groups in Organic Synthesis, 4th ed., Wiley, New York.

3. Evans R. M., Fraser J. B., and Owen L. N. (1949) Dithiols. Part III. Derivatives of polyhydric alcohols. J. Chem. Soc., 248-255.

4. Das B., Saidi Reddy V., and Tehseen F. (2006) A mild, rapid and highly regioselective ring-opening of epoxides and aziridines with acetic anhydride under solvent-free conditions using ammonium12-molybdophosphate. Tetrahedron Lett., 47, 6865-6868.

5. Yadollahi B., and Kabiri Esfahani F. (2007) Efficient preparation of vic-diacetates from epoxides and acetic anhydride in the presence of iron(III)-substituted polyoxometalate as catalyst. Chem. Lett., 36, 676-677.

6. Gansauer A., and Bluhm H. (1998) Dramatic rate acceleration in titanocene catalyzed epoxide opening: cofactors and Lewis acid co-catalysis. Chem. Commun., 19, 2143-2144.

7. Rahman M. A., and Fraser-Reid B. (1985) Actinobolin via the anomeric effect. J. Am. Chem. Soc. 107, 5576-5578.

8. Swindell C. S., and Patel B. P. (1990) Stereoselective construction of the taxinine AB system through a novel tandem aldol-Payne rearrangement annulations. J. Org. Chem., 55, 3-5.

9. Ali S., and Bittman R. (1988) Facile diacylation of glycidyl tosylate. Chiral synthesis of symmetricchain glycerophospholipids. J. Org. Chem., 53, 5547-5549.

10. Sabitha G., Satheesh Babu R., Rajkumar M., Reddy C. S., and Yadav, J. S. (2001) Highly regioselective ring-opening of epoxides and aziridines using cerium(III) chloride. Tetrahedron Lett., 42, 3955-3958.

11. Zeynizadeh B., and Sadighnia L. (2011) One-pot catalytic conversion of epoxides to 1,2-diacetates with hydride transferring agents in acetic anhydride. Synth. Commun. 41, 637-644.

12. Ramesh P., Niranjan Reddy V. L., Venugopal D., Subrahmanyam M., and Venkateswarlu Y. (2001). Zeolite-catalyzed ring-opening of epoxides to acetylated diols with acetic anhydride. Synth. Commun. 31, 2599-2604.

13. Fan, R. H., and Hou, X. L. (2003) Tributylphosphine-catalyzed ring-opening reaction of epoxides and aziridines with acetic anhydride, Tetrahedron Lett., 44, 4411-4413.

14. Azizi N., Mirmashhori B., and Saidi M. R. (2007) Lithium perchlorate-promoted highly regioselective ring-opening of epoxides under solvent-free conditions. Catal. Commun., 8, 21982203. 
15. Dalpozzo R., De Nino A., Nardi M., Russo B., and Procopio A. (2006) 1,2-Diacetates by epoxide ring-opening promoted by erbium(III) triflate. Arkivoc, 6, 67-73.

16. Detry J., Rosenbaum T., Lütz S., Hahn D., Jaeger K. E., Müller M., and Eggert T. (2006) 'Biocatalytic production of enantiopure cyclohexane-trans-1,2-diol using extra cellular lipases from Bacillus subtilis' Appl. Microbiol. Biotechnol., 72, 1107-1116.

17. Aldrich Catalogue of Fine Chemicals, 2013-2014. 